\title{
Entrepreneurial Intention Among Business Students: The Effect of Entrepreneurship Education
}

\author{
Bikram Prajapati, Faculty and Administrator \\ bikramprajapati@westcliff.edu
}

\begin{abstract}
In Nepal, the history of entrepreneurship education is emerging and only few higher educational institutions, such as King's College, Kathmandu University School of Management, Presidential Business School, DAV Business School and Apex College are offering entrepreneurship related courses. Entrepreneurship education is emerging as a subject matter, and institutions are establishing entrepreneurship curriculum and incubation centers to support future entrepreneurs. Research is needed to further explore this subject in terms of its theory and practice in Nepal educational institutes. The purpose of this study is to explore the relationship between entrepreneurship education and entrepreneurial intention considering the theory derived from the planned behavior model (Ajzen, 1991). A stratified random sampling technique was used to select respondents and a standard Likert item questionnaire was distributed amongst 280 business management students who were in their final year at selected colleges. The colleges selected were those who offered entrepreneurship related courses. A total of 181 responses were recorded and used for the analysis. Descriptive analysis, Cronbach's alpha reliability analysis, a multiple linear regression, an ordinary least square test, a correlation matrix, an independent sample T-test and the ANOVA test were implemented in SPSS 20 to determine the relationship between entrepreneurship education and entrepreneurial intention. After analyzing the responses, it was found that entrepreneurship education had a positive but insignificant relationship with entrepreneurial intention. In specific, entrepreneurship education improves the attitude of behavior towards entrepreneurial intention and the perceived behavioral control of students but was found to have insignificant impact on the subjective norm.
\end{abstract}

Keywords: Entrepreneurship education, theory of planned behavior, attitude, perceived behavior control, subjective norm, entrepreneurial intention 


\section{Introduction}

Entrepreneurs solve problems within the market by creating new sustainable business entities. Entrepreneurship is about exploring opportunity, seizing it, and helping entrepreneurs to generate new business opportunities. Integration of entrepreneurship education is an opportunity for universities and colleges to motivate their students to create new ventures which could offer a common value among the individual entrepreneurs and the wider community of Nepal. To a certain extent, entrepreneurship education aids in the unemployment rates of new graduates through helping them to establish new ventures instead of relying on outside sources for employment opportunities. . This type of education promotes an entrepreneurial spirit and culture among potential entrepreneurs and motivates the desire to pursue this career path in the future (Rae, 2010; Dutta, Li, \& Merenda, 2011; Dogan, 2015).

The term, entrepreneurship education, in this study will refer to dynamic processes which positively influence student behavior, norms, and attitudes toward entrepreneurial intention by creating a supportive environment and disseminating information about entrepreneurial traits and behaviors through different academic courses. These courses include but are not limited to innovation management, entrepreneurship and new venture creation, business design, entrepreneurial marketing, and strategic thinking. According to Dogan (2015), this type of education promotes the,

"feeling of independence and selfconfidence to individuals, enables the recognition of alternative career options, broadens the individuals' horizons by enabling them to better perceive the opportunities and provides the knowledge that individuals will use in developing new business opportunities" (p. 92)

In Nepal, a developing country, government and private organizations are encouraging entrepreneurial activities through education to promote the value of entrepreneurship (Karki,

2014). Awareness of the need for entrepreneurship education in Nepal is growing, but a limited amount of research has been conducted in how these courses impact the entrepreneurial field. Thus, entrepreneurship education needs to be explored in terms of theory and practice in Nepal. In Nepal, the history of entrepreneurship education is emerging and only a few higher education institutions such as King's College, Kathmandu University School of Management, Nepal School of Entrepreneurship, Apex College and DAV Business School are offering entrepreneurship courses currently. The subject matter is gaining popularity amongst management students; however, there is a lack of relevant and contextual literature which explores the effect of entrepreneurship education on entrepreneurial intentions. According to the International Labor Organization (2016), the unemployment rate among higher education graduates in Nepal is $26.1 \%$ and is expected to grow even higher in the coming years as there continues to be a mismatch of skills among graduates and employers. Most higher education graduates in Nepal either opt for a job or choose to stay unemployed while they are searching for a job that fits. Only a few graduates choose to enter into self-employment via entrepreneurial venture.

The success or failure of an entrepreneurial venture relies upon not only prior education, but the personal traits of the potential entrepreneur. Timmons (1994) explains that the characteristics of successful entrepreneurs include commitment and determination, creativity, adaptability, risk-taking, leadership quality and opportunity seizing (as cited in Rahman \& Singh, 2013). Rahman and Singh (2013) prove that innovation, a futuristic mindset, risk-taking ability, adaptability and commitment motivate entrepreneurs to create new ventures. Additionally, entrepreneurs are generally those who look for opportunities, are goal oriented, display creativity, confidence, trustworthiness and ambition, and have an internal locus of control (Nandram \& Samsom, 2007). This study will explore whether these traits can be developed through education and if education can help to develop entrepreneurship intention within a student.

This study is following the entrepreneurial intention model of Ajzen's (1991) theory of planned behavior model which explains that attitude towards entrepreneurial behavior, 
perceived social norms and perceived behavior control influence entrepreneurial intention. In this study, entrepreneurial intention is defined as an individual's personal orientation like desire, attitude, and how orientation influences a student's decision to become self-employed.

\section{Literature Review}

A significant amount of research has been conducted to explain the effect of entrepreneurship education on entrepreneurial intention among a student. This literature review section explains the concepts of entrepreneurial intentions as response variables. A detailed discussion about entrepreneurship education and its relationship with the theory of planned behavior model and entrepreneurial intentions will be elaborated upon. A study of scholarly articles in the literature review section introduces entrepreneurial intention, concepts and different entrepreneurial theory which has been considered to explain entrepreneurial intention. In consecutive sections, concepts of entrepreneurship educations were defined and elaborated its relationship with the attitude towards the action, social norms and perceived behavioral control. A research paper which explains the effects of entrepreneurship education in entrepreneurial intention has been reviewed and considered to explain research scope.

Entrepreneurial intention can be described as an individual desire to establish and run one's own startup company (Krueger, Reilly, \& Carsrud, 2000). In the education process, entrepreneurial attitudes, behaviors and perception towards viability and success of innovative ideas have an impact on students' intentions to become entrepreneurs. The entrepreneurial event model (EEM), curated by Shapero and Sokol (1982), demonstrates how entrepreneurial intent is an individual mindset used to establish a new venture, attain viability and prosper in the market (as cited in Carsrud, Krueger, \& Reilly, 2000). An entreprenurial intent is derived from individual beliefs and norms. The theory of planned behavior (TPB), offered by Ajzen (1991), theorizes that intention is defined by an entrepreneur's attitude, subjective norms, and controllable behavior. Lastly, the entrepreneurial potential model (EPM), proposed by Brazeal and Krueger (1994), explains how entrepreneurial intention refers to the perceptions, desirability and the feasibility of a new idea or new venture. Convenience, need for achievement, the viability of an idea, and attitude are the key intents of entrepreneurship among university students (Velasquez, Arias, Hernandez, Diez-Echavarria, Marin, \& Perez, 2018).

Souitaris, Zerbinati, and Al-Laham (2007) explained that entrepreneurship education positively influences individuals' attitudes towards behavior, subjective norms, and perceived behavioral control and entrepreneurial intentions.

The European Commission analyzed the significance of entrepreneurship programs in higher education institutions through the use of a study and control group (European Commission, 2012). In this research, a total of 851 entrepreneurship alumni, 1,482 control group alumni and 288 JADE alumni of 43 higher education institutions participated by completing an online questionnaire. The results showed that entrepreneurship education is vital to the development of entrepreneurial skills and attitudes as well as improved intention towards entrepreneurship and individual employability (European Commission, 2012). Specifically, Balaban and Ozdemir (2008) believe that entrepreneurship education plays a vital role in creating self-awareness within an individual regarding entrepreneurship characteristics. It was also found to positively impact an individual's determination and perseverance, help them to deal with challenges and motivate individuals to start their own businesses (Izedonmi \& Okafor, 2010; Kuttim, Kallaste, Venesaar, \& Kiis, 2014; Kalyoncuoglu, Aydıntan, \& Goksel, 2017).

Overall, research supports the fact that entrepreneurship education plays a positive role in the development of entrepreneurship intention (Maresch, Harms, Kailer, \& Wimmer-Wurm, 2016; Dohse \& Walter, 2010; Alain \& Gailly, 2004; McStay, 2008; Gelard \& Saleh, 2011). However, Goksel and Aydintan's (2011) sampled 175 business administration students in Turkey and concluded that education does not have a significant relationship with entrepreneurial intentions. Abdullahi, Zainol, Daud, and Yazid, (2017) implemented a random sampling method among final year university students and analyzed data using the structural equation modeling approach, which found that entrepreneurship education has a negative relationship with 
entrepreneurial intentions. Specifically, this explained that entrepreneurship education also shows the physical and mental pain resulted from limited resources, lack of supportive environment, environmental changes and failure in early career etc. and struggle required to be an entrepreneur and highlighted the risk associated with entrepreneurship (Abdullahi, Zainol, Daud, and Yazid, 2017; Abdullahi et.al, 2017). Thus, students might opt to pursue a salaried job that is determined to have a lower risk. Additional research done by Efrata, Hadiwidjojo, Solimun, \& Aisjah (2016) among 209 Management and Business Students in Indonesia Universities; Oosterbeek, Van Praag, and ljsselstein (2008) research confirmed that entrepreneurship education has a negative relationship with entrepreneurial intention. Tsordia and Papadimitriou (2015) research showed that final year studenta who completed business courses expressed lower entrepreneurial intention than that of first-year students.

According to the theory of planned behavior, in general, individual attitudes towards behavior, subjective norms, and perceived behavioral control influence an individual's behavioral intentions (Ajzen,1991). It is an individual's beliefs and attitude which inform their mindset to desire selfemployment. There has been a confirmed positive relationship between attitude towards behavior and entrepreneurial intention and it has a strong influence on developing positive intention (Dohse \& Walter, 2010; Frazier \& Niehm, 2006; Keong, 2008; Tsordia \& Papadimitriou, 2015).

Subjective norm refers to individual views about social pressure which influence individuals to behave in a certain way. Linan and Chen (2006) show the influence of family, friends and other important people have a great impact on the formation of intention. However, subjective norm is not the strongest influencer in developing positive entrepreneurial intention (Krueger, Reilly, \& Carsrud, 2000; Tsordia \& Papadimitriou 2015; Kalyoncuoglu, Aydıntan, \& Goksel 2017; Linan \& Chen 2009; Mohammed, Fethi, \& Djaoued 2017). While a majority of the literature found supports this conclusion, Yordanova and Tarrazon's (2010) research shows the subjective norm has a significant role in defining intention.

Perceived behavioral control refers to an individual's self-esteem and confidence to perform desired work. Ajzen (1991) analyzed an entrepreneur's past experience to evaluate whether a task could be performed or not. Dohse and Walter (2010); Frazier and Niehm (2006); Keong (2008); Krueger, Reilly, and Carsrud (2000); Tsordia and Papadimitriou (2015), Kristiansen and Indarti (2004) explain that there is a positive and significant relationship between perceived behavioral control and entrepreneurial intention.

A different research on the area of entrepreneurship education resulted different impact on the student's behavior, attitude, subjective norms and finally in entrepreneurial intentions. While entrepreneurship studies have gained popularity and considered as an important factor to develop positive entrepreneurial intention among students, there is no empirical evidence among management students of Kathmandu, Nepal. A lot of research was done to explain the direct relationship between entrepreneurship education, theory of planned behavior with entrepreneurial intention. A literature does not explain how entrepreneurship education impact on the theory of planned behavior and its effect on entrepreneurial intention. This research explains the effect on entrepreneurship education on the attitude towards the action, social norms and perceived behavioral control and its effects on entrepreneurial intention. Entrepreneurial intention is situational factor. Thus, a research should be explored in the context to conclude its relationship.

\section{Objectives of the Study}

The objective of this study is to analyze the relationship between entrepreneurship education and entrepreneurial intentions among management students of selected colleges located in Kathmandu, Nepal. This study will explore how entrepreneurship education impacts the development of entrepreneurial attitude, how it effects the subjective norm and how it impacts the behavior towards pursuing entrepreneurship as a career.

\section{Conceptual Framework and Hypotheses}

This research will follow the theory of planned behavior framework proposed by Ajzen (1991). Attitude toward behavior, subjective norms, and perceived behavioral control are the building 
blocks of behavioral intention. Ajzen's (1991) theory of planned behavior is a strong predictor of entrepreneurial intention, and a lot of research has been conducted to measure its effects in impacting entrepreneurial intention among college students in a western context. However, research is still needed to determine this connection within an eastern context, specifically in Nepal. Therefore, this research will analyze how, following the theory of planned behavior, entrepreneurship education affects entrepreneurial intention within the context of Kathmandu, Nepal.

This research will use the theory of planned behavior as a basis for determining entrepreneurial education's effect on entrepreneurial intention due to the determination that the theory of planned behavior can be applied to predict entrepreneurial intention in different cultural contexts (Davids, 2017). Further, this research adheres to Ajzen's (1991) finding that the attitudes toward behavior, subjective norms, and perceived behavioral control can predict intention to describe different kinds of behavior with high accuracy. Based on this, the motivational level of people engaging in certain behavior for development and growth of entrepreneurial intentions can be ascertained. A positive feeling towards own intention encourages engagement in that behavior. Thus, in this study three factors of theory of planned behavior has been considered.

Figure 1 is the intention model derived for this research and shows the relationship between entrepreneurship education, theory of planned behavior and entrepreneurial intention. The intention model will be used to explain students' intentions to choose their career as an entrepreneur. The effect of entrepreneurship education on the theory of planned behavior and entrepreneurial intention and effect of the theory of planned behavior of entrepreneurial intention were considered.

The intention model will be used to the explain relationship between entrepreneurship education, theory of planned behavior and entrepreneurial

were selected to conduct the research. A total of 8 education institutions replied to our inquiry of being involved in the study. These 8 educational institutions agreed to share our questionnaire with their final year management students. A total of 181 responses were received from final year intention. Subjective norms represent external environment influence on other to pursue an entrepreneurial career. This research measure influence and impact of friends, family person on student's decision. In this research perceived behavior control explain students believe to perform entrepreneurial activities. It analyzes student reflection of the past experience impact on his/her behavior in the future. An individual will evaluate whether an activity/task is simple, or complex, based on available resources and skills. A reaction of students of an entrepreneurship education influence on development of intentions.

Based upon the information determined by the literature review, the following hypotheses have been formulated.

- H1: There is a statistically significant relationship between entrepreneurship education and entrepreneurial intention among students in Kathmandu, Nepal.

- H2: There is a statistically significant relationship between attitude to behavior, perceived behavioral control subjective norms and entrepreneurial intention in Kathmandu, Nepal.

- H3: There is a statistically significant relationship between entrepreneurship education and attitude to behavior, perceived behavioral control and subjective norms in Kathmandu, Nepal.

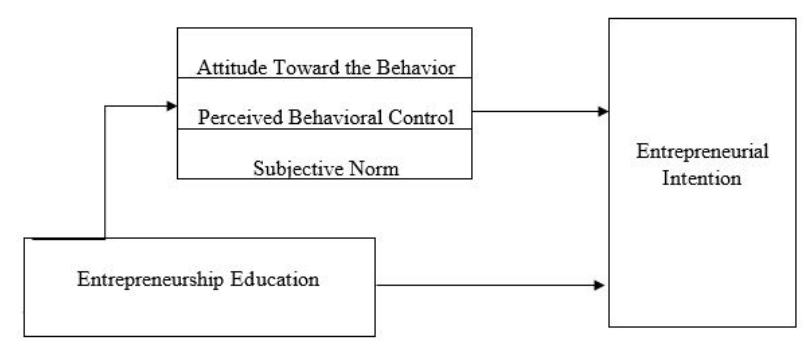

\section{Research Methodology}

Populations and Sample Size. Final year students who were currently enrolled in management education at King's College,

Figure 1. Entrepreneur intention model

students of the aforementioned higher education institutions.

Table 1 summarizes the demographical profile of the respondents. A total 181 respondent responses were used for this research. Out of 181 respondents, 89 (49.2\%) were female and 92 
(50.8\%) were male. 82 (45.3\%) were from graduate (MBA) programs and $99(54.7 \%)$ were from undergraduate (BBA) programs. 60 (33.1\%) were aged below 25 and 121 (66.9\%) were aged above 25. $91(50.3 \%)$ students were running family businesses and 90 (49.7\%) students were not associated with any family business.

Research instrument. A standard questionnaire was used to measure attitude of the sample group of students toward behavior, social norms, perceived behavior control, and entrepreneurial intention. Items were adopted from Linan (2009). To measure student perception towards entrepreneurship education, a seven-point threeitem Likert scale, developed by Utami (2017), was used.

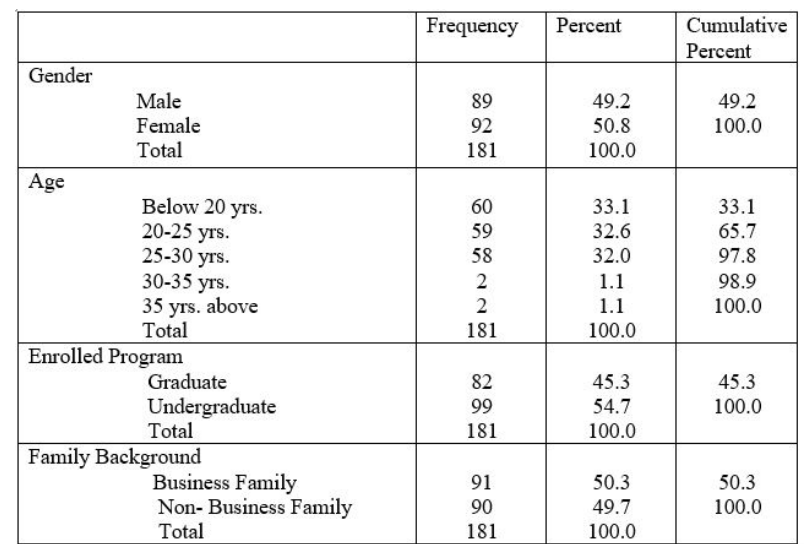

Table 1. Demographics profile of 181 respondents

Data analysis. This research used SPSS 20.0 software to perform the analysis of the data collected. Cronbach's alpha was tested in each dimension. Descriptive statistics, linear regression, Independent T- test and a correlation analysis were used to test the stated derived hypotheses.

\section{Scale of Measurement}

Reliability test. Table 2 shows the reliability statistics, or Cronbach's values, for the variables used throughout this research. The reliability of the independent and dependent variables was greater for reach item than the threshold value of 0.7. Thus, this confirms internal consistency.

\section{Test of Ordinary Leas Square (OLS) Assumption}

Normality test. The linearity of the data set was examined by plotting ZRESID and ZPRED as shown in Figure 2. The graph shows that there are not any identifiable nonlinear relationships with the dependent variable, or entrepreneurial intention. The Kolmogorov-Smirnov test $(p=0.200)$ and Shapiro-Wilk test $(p=0.573)$, as it is greater than 0.05 in value, confirm that the data was normally distributed. As cited in Asghar and Zahediasl (2012), normality assumptions for a sample size greater than 30 are always valid, and anything greater than this will not cause any major problems in the analysis. The sampling distribution for a large sample size is always normally distributed.

\begin{tabular}{|l|l|l|}
\hline Construct & Cronbach's Alpha & Number of Items \\
\hline Entrepreneurship Education & .765 & 3 \\
\hline Attitude Toward The Behavior & .799 & 5 \\
\hline Subjective Norm & .773 & 4 \\
\hline Perceived Behavioral Control & .886 & 6 \\
\hline Entrepreneurial Intention & .912 & 8 \\
\hline
\end{tabular}

Table 2. Reliability analysis

Multicollinearity test. To test the presence of multicollinearity issues in the regression, the model variance inflation factor (VIF) was performed. The VIF value lies between 1.092 to 1.345 , which indicates that there is not a multicollinearity problem (Sekaran \& Bougie, 2010).

Heteroscedasticity test. The heteroscedasticity test was examined through a graphical plot of standardized predicted values (ZPRED)and standardized residuals (ZRESID) in the SPSS. This test examines an important assumption of the linear regression model, the residuals are homogeneously distributed. The nature of graph determine whether there is heteroscedasticity or not. This test did not show a heteroscedasticity problem in the datasheet, which is proven in Figure 2. 


\section{Normal P-P Plot of Regression Standardized Residual}

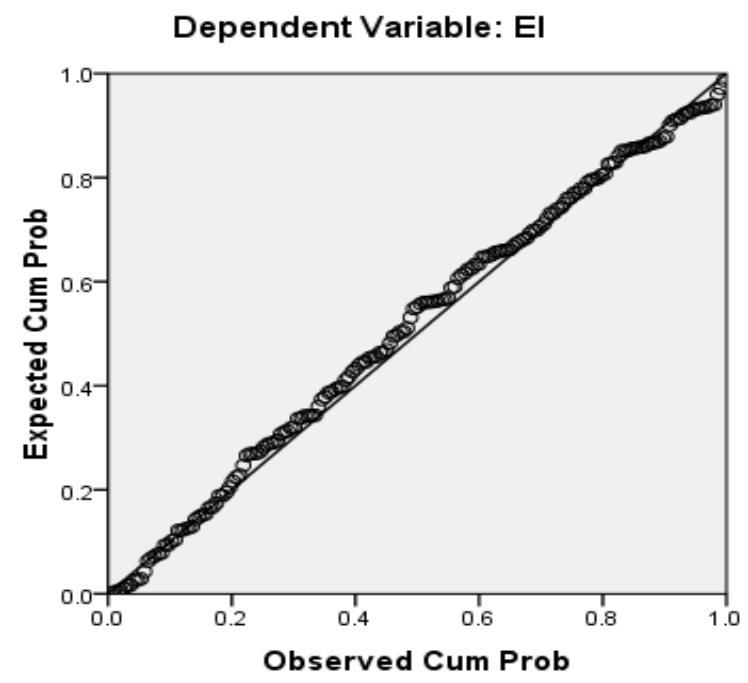

Figure 2. Regression standardized residual plot.

Autocorrelation test. The Durbin Watson test was being performed to check the autocorrelation in residuals from a regression analysis. With reference to the standard Durbin Watson table, a value of $d l=1.633$ and $d u=1.715$ (for nearest value $\mathrm{n}=200$ and $k=4)$, and a calculated $p$-value $(\mathrm{p}=1.987)$ lies between $1.715(\mathrm{du})$ and 2.285 (4-du). The conclusion drawn from this test was that there was no autocorrelation in the given data.

\section{Multiple Linear Regression Analysis}

The multiple linear regression model summary, as seen in Table 3, shows the $56.8 \%$ of variation found in the dependent variable is explained by an attitude toward behavior, subjective norm, perceived behavioral control, and entrepreneurship education. A relationship between entrepreneurial intention and the predictor was found to be statistically significant ( $F=57.847, P=0.000<0.05)$.

Table 4.1 shows the equation used to describe the relationship between attitudes toward behavior, subjective norms, perceived behavioral control, and entrepreneurship education with entrepreneurial intention. Standardized beta coefficients measured an effect in the dependent variable for one unit of change in the independent variable while holding other independent variables constant.

Based on the regression analysis coefficient results listed in Table 4.1, the relationship among dependent and independent variables can be explained through the following formula:

$$
\begin{aligned}
& \mathrm{EI}=(1.535)+.003 \mathrm{EE}+.909 \mathrm{ATB}+(.037) \mathrm{SN}+.355 \mathrm{PBC} \\
& \text { Where, } \\
& \mathrm{EI}=\text { Entrepreneurial Intention } \\
& \mathrm{EE}=\text { Entrepreneurship Education } \\
& \mathrm{ATB}=\text { Attitude toward the Behavior } \\
& \mathrm{SN}=\text { Subjective Norms } \\
& \mathrm{PBC}=\text { Perceived Behavioral Control }
\end{aligned}
$$

Thus, it has been determined that there is a positive relationship between entrepreneurial intention and entrepreneurial education, attitude towards behavior and perceived behavior control. There was an identified negative relationship with the subjective norm.

While holding other independent variables in the model constant, if there was a one-unit increase in attitude towards behavior, there would be a subsequent increase of 0.909 units in entrepreneurial intention. This shows El is strongly dependent upon individual beliefs regarding the outcome of behavior. It indicates that when 
students feel that their behavior will lead to the creation of a new startup, they will be more motivated to work on that project. The more they believe in their own ideas and are able to forecast a future where they could potentially start their own startup, they will display higher levels of entrepreneurial intention.

\begin{tabular}{|l|r|r|r|r|}
\hline Model & R & R Square & Adiusted R Square & $\begin{array}{c}\text { Std. Error of the } \\
\text { Estimate }\end{array}$ \\
\hline 1 & $.754^{\mathrm{a}}$ & .568 & .558 & .86263 \\
\hline
\end{tabular}

Table 3. Multiple regression model summary.

Note. The predictors variables used in the regression model were attitudes toward behavior, subjective norms, perceived behavioral control, entrepreneurship education and dependent variables to determine entrepreneurial Intention.

\begin{tabular}{|c|c|c|c|c|c|c|}
\hline \multirow{2}{*}{\multicolumn{2}{|c|}{ Model }} & \multicolumn{2}{|c|}{$\begin{array}{c}\text { Unstandardized } \\
\text { Coefficients }\end{array}$} & \multirow{2}{*}{$\begin{array}{c}\text { Standardized } \\
\text { Coefficients } \\
\text { Beta } \\
\end{array}$} & \multirow[b]{2}{*}{$\mathrm{T}$} & \multirow[b]{2}{*}{ Sig. } \\
\hline & & B & Std. Error & & & \\
\hline \multirow[t]{5}{*}{1} & (Constant) & -1.535 & .566 & & -2.713 & .007 \\
\hline & $\mathrm{EE}$ & .003 & .077 & .002 & .042 & .966 \\
\hline & ATB & .909 & .084 & .623 & 10.834 & .000 \\
\hline & $\mathrm{SN}$ & -.037 & .068 & -.027 & -.538 & .591 \\
\hline & PBC & .355 & .060 & .306 & 5.915 & .000 \\
\hline
\end{tabular}

a. Dependent Variable: EI

Table 4.1. Regression coefficient

Similarly, if there was one-unit increase in PBC, El would subsequently increase by 0.355 . This means that students who show higher perceived behavior control exhibit higher levels of entrepreneurship intention. Self-assessment and self-belief when performing entrepreneurial activities improves intention to start a new venture.

The relationship between perception towards entrepreneurship education and their entrepreneurial intention is minutely positive. If there is a one-unit increase in EE, there is only a subsequent increase of 0.003 in El. This shows that $\mathrm{EE}$ is not a strong predictor of El directly. Entrepreneurship education provides theoretical as well as practical knowledge to students. It influences students' career decisions regarding if they will eventually become entrepreneurs.
However, EE also explains the hard work, sacrifice, pain and strong dedication needed to become a successful entrepreneur in the future, which might generate negative thoughts amongst students regarding running their own ventures. Thus, the results show a weak relationship between EE and El.

For every unit of increase in the subjective norm, El decreases by 0.037 units as the other factors remain constant. The social pressure has a negative impact on El. Entrepreneurial intention is more dependent on an individual's own experience and is highly influenced by the availability of a support system in the individual's ecosystem.

Figure 3 summarizes the influence of entrepreneurship education on attitude to behavior, perceived behavioral control and 
subjective norm individually. The regression coefficients are represented in Figure 3.

Entrepreneurship education has a significant impact on the development of a positive attitude toward entrepreneurial behavior, and it accounted for the $21.8 \%$ variation in attitude toward the behaviors. When a student is familiar with an entrepreneurial ecosystem and connects with the entrepreneurial network system, they become

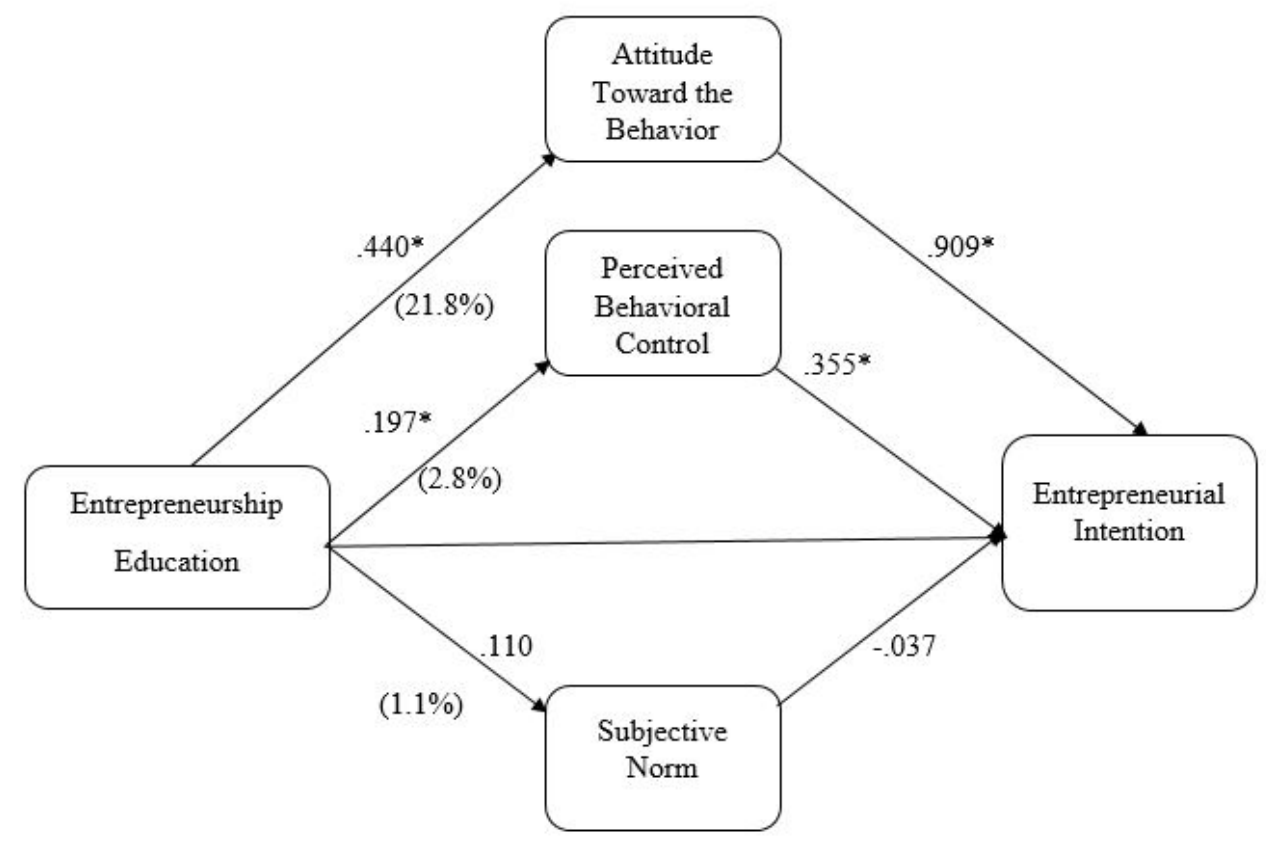

* Significant regression coefficients, $p<0.05$

Figure 3. Model summary.

created. The test was run considering the square

more confident in their ideas and are more willing to try and become an entrepreneur. EE has a significant positive impact on perceived behavior control as can be seen by the $2.8 \%$ variation. When viewed through the regression model, entrepreneurship education contributes only $2.8 \%$ to make changes in perceived behavior control of an entrepreneur. It was found that EE has an insignificant and weak relationship with $\mathrm{SN}$ as can be seen by the $1.1 \%$ variation. It can be concluded that EE has a high impact on El, thus indirectly influencing the attitude of potential entrepreneurs.

\section{Functional Form Specification Test}

Ramsey's RESET (regression specification error test) test was performed to determine the presence of nonlinear relationship in the regression model (Ramsey 1969). To test the nonlinear relationship, two new variables, the square and cube of the predicated El value, were and cube of the predicated EI, EE, ATB, PBC, SN as explanatory variables and $\mathrm{El}$ as the dependent variable. The coefficients of higher predicated Value are significant concluding a linear relationship between the dependent and independent variables.

\section{Correlation Analysis}

According to the correlation matrix, as seen in Table 5, a correlation coefficient between entrepreneurial intention and attitude toward a behavior is 0.694 , significant at the level of 0.01 $(p=0.000)$. This indicates a high positive relationship among El and ATB. The correlation coefficient between entrepreneurial intention and entrepreneurship education is 0.341 , significant at 0.01 level $(p=0.000)$, which indicates a weak positive relationship between $\mathrm{EI}$ and $\mathrm{EE}$. The correlation coefficient between entrepreneurial 
intention and subjective norm is .140 , insignificant at the level of $0.01(p=0.06)$. It shows a very weak positive relationship and is not statistically significant. The correlation coefficient between entrepreneurial intention and perceived behavioral control is 0.454 , significant at the level of $0.05(p=0.00)$, which indicates a moderate relationship between $\mathrm{PBC}$ and El.

\begin{tabular}{|c|c|c|c|c|c|c|}
\hline \multicolumn{7}{|c|}{ Correlations } \\
\hline & & $\mathrm{EE}$ & ATB & SN & $\mathrm{PBC}$ & EI \\
\hline \multirow[t]{3}{*}{$\mathrm{EE}$} & Pearson Correlation & 1 & $.467^{* *}$ & .107 & $.167^{*}$ & $.341^{* *}$ \\
\hline & Sig. (2-tailed) & & .000 & .152 & .025 & .000 \\
\hline & $\mathrm{N}$ & & 181 & 181 & 181 & 181 \\
\hline \multirow[t]{3}{*}{ ATB } & Pearson Correlation & & 1 & $.176^{*}$ & $.245^{* *}$ & $.694^{* *}$ \\
\hline & Sig. (2-tailed) & & & .018 & .001 & .000 \\
\hline & $\mathrm{N}$ & & & 181 & 181 & 181 \\
\hline \multirow[t]{3}{*}{$\mathrm{SN}$} & Pearson Correlation & & & 1 & $.188^{*}$ & .140 \\
\hline & Sig. (2-tailed) & & & & .011 & .060 \\
\hline & $\mathrm{N}$ & & & & 181 & 181 \\
\hline \multirow[t]{3}{*}{$\mathrm{PBC}$} & Pearson Correlation & & & & 1 & $.454^{* *}$ \\
\hline & Sig. (2-tailed) & & & & & .000 \\
\hline & $\mathrm{N}$ & & & & & 181 \\
\hline \multirow[t]{3}{*}{ EI } & Pearson Correlation & & & & & 1 \\
\hline & Sig. (2-tailed) & & & & & \\
\hline & $\mathrm{N}$ & & & & & \\
\hline
\end{tabular}

Table 5. Correlation matrix

\section{Relationship between Demographic Variables and Entrepreneurial Intention}

This research further analyzed the relationship between the demographic variables of gender, age, program, and family background with entrepreneurial intention. According to Tstatistics, it has been shown that there is no significant relationship between gender and program with a student's entrepreneurial intention. However, there was significant relationship determined among family background and entrepreneurial intention. The mean value shows that students who were a part of a family business showed more entrepreneurial intention than those who did not have a family business in their background. These results can be seen in Table 6 below.

The ANOVA test results, represented in Table 7 , showed that there is no statistically significant relationship between the age of students and their entrepreneurial intentions. It signifies that development of entrepreneurial intention is not dependent upon the age of students.

\section{Implications}

Entrepreneurship education offered in the higher education institution has a positive impact on developing entrepreneurial intention, but not in greater intensity as it should be. Also, entrepreneurship education offered in higher education might not change the behavior of students so quickly. It required time to change attitude and behavior. Thus, to develop the entrepreneurial intention among student government and educational institution should collaborate. As entrepreneurship education was determined to have a significant impact on entrepreneurship intention, the government and policy makers in Nepal should work together to begin introducing the concepts of entrepreneurship education and training starting at the secondary educational level. They should work with existing schools to create a conducive environment for entrepreneurship. By integrating entrepreneurship in the curriculum at an early age, student's perceived behavior could be changed positively towards higher entrepreneurship intention. 
Higher education institutions should introduce entrepreneurship specialization courses in their curriculums. This addition will not only increase awareness about entrepreneurship, but it will also motivate students to start a new venture. An entrepreneurship environment in higher education, such as through the inclusion of a business incubation center, could curate seed funding for students. This could, in turn, instill a sense of belief amongst students that embarking on a new venture is possible. Workshops,

\begin{tabular}{|c|c|c|c|c|c|c|}
\hline \multirow{9}{*}{$\begin{array}{l}\text { Entrepreneurial } \\
\text { Intention }\end{array}$} & Gender & $\mathrm{N}$ & Mean & $\begin{array}{c}\text { Std. Error } \\
\text { Mean }\end{array}$ & t-value & $\begin{array}{l}\text { Sig. (p) } \\
\text { (2-tailed) }\end{array}$ \\
\hline & Male & 89 & 5.2275 & .12718 & \multirow[b]{2}{*}{1.508} & \multirow[b]{2}{*}{.133} \\
\hline & Female & 92 & 4.9375 & .14361 & & \\
\hline & Program & & & & & \\
\hline & Undergraduate & 82 & 4.9832 & .14854 & \multirow[b]{2}{*}{-.914} & \multirow[b]{2}{*}{.362} \\
\hline & Graduate & 99 & 5.1604 & .12647 & & \\
\hline & Family Background & & & & & \\
\hline & Business Family & 91 & 5.3255 & .11880 & \multirow[b]{2}{*}{2.599} & \multirow[b]{2}{*}{0.010} \\
\hline & $\begin{array}{l}\text { Non Business } \\
\text { Family }\end{array}$ & 90 & 4.8319 & .14846 & & \\
\hline
\end{tabular}

Table 6. T-test Result: Gender, program and family background with entrepreneurial intention

\begin{tabular}{|l|l|c|c|c|c|c|}
\hline \multirow{5}{*}{$\begin{array}{l}\text { Entrepreneurial } \\
\text { Intention }\end{array}$} & \multicolumn{1}{|c|}{ Age } & $\mathrm{N}$ & Mean & Std. Error & F- value & Sig. (p) \\
\cline { 2 - 6 } & Below 20 Yrs. & 60 & 5.0833 & .17255 & & \\
\cline { 2 - 5 } & $20-25$ yrs. & 59 & 4.8305 & .17690 & \multirow{2}{*}{1.657} & \multirow{2}{*}{.178} \\
\cline { 2 - 5 } & $25-30$ yrs. & 58 & 5.2780 & .15477 & & \\
\cline { 2 - 6 } & $30-35$ yrs. & 4 & 5.8438 & .51633 & & \\
\cline { 2 - 6 } & Total & 181 & 5.0801 & .09646 & & \\
\hline
\end{tabular}

Table 7. One-way ANOVA analysis: Age and entrepreneurial intention

conferences, networking sessions, idea pitching, and boot camp programs should be initiated by higher education institutions to develop an environment conducive to encouraging entrepreneurship practices.

Limitations and Areas of Further Research

This data has been collected from select management colleges located in the Kathmandu, Nepal, and thus, we cannot generalize the results for other institutions or locations. The limited sample number was due to the scope of the target audience, which was final semester students of undergraduate and graduate management programs located in Kathmandu, Nepal.

This research indicated a positive relationship between entrepreneurship education and intention among students without considering a control group. Thus, further research can be done to analyze entrepreneurial intention with the integration of a control group and treatment group. It can be done by comparing entrepreneurial intention levels among graduate students who are already enrolled within entrepreneurship courses and those who have yet to start an entrepreneurship program. This research did not consider the intensity of entrepreneurship education, such as the number of entrepreneurship related courses taken, length of courses, student participation in entrepreneurship related workshops, etc. Thus, further research is needed to explore what impact intensity of entrepreneurship education has on entrepreneurial intention.

Second, the current study revealed that entrepreneurship education has more of an impact on developing positive student attitudes toward behavior than its direct effect on entrepreneurial intention. Thus, further research needs to be 
conducted regarding entrepreneurial attitude as a mediating variable.

Third, this current study was conducted without consideration of teaching methods. Thus, in future research, it will be interesting to analyze how teaching methods implemented to facilitate entrepreneurship education impacts student entrepreneurial intention.

Future research is recommended to study entrepreneurship intention amongst students using a larger sample size.

\section{Conclusion}

This study has analyzed the relationship between attitude and behavior, perceived behavioral control and subjective norm, as well as entrepreneurship education and entrepreneurial intention among management students of the selected colleges in Kathmandu, Nepal.

The following conclusions can be drawn from the analysis:

- Attitude toward the behavior has a positive and significant relationship with entrepreneurial intention.

- Perceived behavior control has a positive and significant relationship with entrepreneurial intention.

- Subjective norm has a negative but insignificant relationship with entrepreneurial intention.
- Entrepreneurship education has a positive but insignificant relationship with entrepreneurial intention.

- Entrepreneurship education has a positive and significant impact on attitude to behavior and perceived behavioral control.

- Entrepreneurship education has a positive but insignificant impact on a subjective norm. 


\section{REFERENCES}

Abdullahi, A. I., Zainol, F. A., Daud, W. N., \& Yazid, A. S. (2017). Entrepreneurial Intention Revisited: Measuring the Impact of Socio-Cultural Business Environment using Structural Equation Modeling. World Applied Sciences Journal, 35(8), 1445-1456. doi:10.5829/idosi.wasj

AlainF., \& Gailly, B. (2004). Using the Theory of Planned Behavior to Assess Entrepreneurship Teaching Program: A First Experimentation. Paper presented at 14th Annual IntEnt Conference. University of Napoli Federico II, Italy.

Asghar, G., \& Zahediasl, S. (2012). Normality tests for statistical analysis: A guide for non-statisticians. Int J Endocrinol Metab, 10(2), 486-489. doi:10.5812/ijem.3505

Brazeal, D., \& Krueger, N. (1994). Entrepreneurial potential and potential entrepreneurs. Entrepreneurship Theory and Practice, 18(1), 5-21. http://dx.doi.org/10.1016/S0883-9026(98)00033-0

Carsrud, A. L., Krueger, N. F., \& Reilly, M. D. (2000). Competing models of entrepreneurial. Journal of Business Venturing, 15(5), 411-432. Retrieved from https://www.sciencedirect.com/science/article/abs/pii/S0883902698000330

Dogan, E. (2015). The effect of entrepreneurship education on entrepreneurial intention of university students in Turkey, 79-93. Retrieved from https://www.researchgate.net/publication/320474395

Dohse, D., \& Walter, S. G. (2010). The role of entrepreneurship education and regional context in forming entrepreneurial intentions. Documents de treball IEB, 18, 2010. Retrieved from https://www.researchgate.net/publication/43950397

Dutta, D. K., Li, J., \& Merenda, M. (2011). Fostering entrepreneurship: Impact of specialization and diversity in education. International Entrepreneurship and Management Journal, 7(2), 163-179. Retrieved from https://link.springer.com/article/10.1007/s11365-010-0151-2

Efrata, T., Hadiwidjojo, D., Solimun, S., \& Aisjah, S. (2016). Entrepreneurship Education and Entrepreneurial Role Models: How Do They Affect Entrepreneurial Intentions? Australian Journal Basic \& Applied Sciences, 10(8), 53-59. Retrieved from https://ssrn.com/abstract=2766772

Frazier, B. J., \& Niehm, L. S. (2006). Predicting the entrepreneurial intention of non-business majors: A preliminary investigation. Retrieved from https://pdfs.semanticscholar.org/b59f/f4ad4f8187fb6e777149b24aadc9c68c79ef.pdf

Gelard, P., \& Saleh, K. E. (2011). Impact of some contextual factors on entrepreneurial intention of university students. African Journal of Business Management, 5(26), 10707-10717. doi:10.5897/AJBM10.891

Goksel, A., \& Aydıntan, B. (2011). Gender, business education, family background and personal traits, a multidimensional analysis of their effects on entrepreneurial propensity: Findings from Turkey. International Journal of Business and Social Science, 2(13), 35-48. Retrieved from http://ijbssnet.com/journals/Vol._2_No._13_Special_Issue_July_2011/5.pdf

Izedonmi, P. F., \& Okafor, C. (2010). The effect of entrepreneurship education on students' entrepreneurial intentions. Global Journal of Management and Business Research, 10(6), 49-60. Retrieved from https://www.researchgate.net/publication/265498372

Kalyoncuoglu, S., Aydıntan, B., \& Goksel, A. (2017). The effect of entrepreneurship education on entrepreneurial intention: An experimental study on undergraduate business students. Journal of Management Research, 9(3), 72-91. Retrieved from https://www.researchgate.net/publication/318344584

Karki, B. B. (2014). Entrepreneurship Development Programme with Reference To Small Enterprises in Nepal. Janapriya Journal of Interdisciplinary Studies, 3, 16-22. Retrieved from https://www.nepjol.info/index.php/JJIS/article/view/17893/14524

Keong, L. C. (2008). Entrepreneurial intention: An empirical study among open university Malaysia students. [Scholar project]. Open University Malaysia Center for Graduate Studies. Retrieved from http://library.oum.edu.my/repository/306/1/Entrepreneurial_Intention_An_Empirical_Study_among_OU M_Students.pdf

Kristiansen, S., \& Indarti, N. (2004). Entrepreneurial intention among Indonesian and Norwegian students. Journal of Enterprising Culture, 12(1), 55-78. https://doi.org/10.1142/S021849580400004X

Kuttim, M., Kallaste, M., Venesaar, U., \& Kiis, A. (2014). Entrepreneurship education at university level and students' entrepreneurial intentions. Procedia-Social and Behavioral Sciences, 110(2014), 658-668. doi: 10.1016/j.sbspro.2013.12.910 
Linan, F. (2004). Intention-based models of entrepreneurship education. Piccola Impresa/Small Business, 3(1), 1135. Retrieved from https://www.researchgate.net/publication/235937886

Linan, F., \& Chen, Y. W. (2009). Development and cross-cultural application of a specific instrument to measure entrepreneurial intentions. Entrepreneurship Theory and Practice, 33(3), 593-617. http://dx.doi.org/10.1111/j.1540-6520.2009.00318.x

Linan, F., \& Chen, Y. W. (2006). Testing the entrepreneurial intention model on a two-country sample. Documents de Treball (Universitat Autònoma de Barcelona. Departament d'Economia de l'Empresa). 7/06. Retrieved from https://www.researchgate.net/publication/28117836

Mahendra, A. M., Djatmika, E. T., \& Hermawan, A. (2017). The effect of entrepreneurship education on entrepreneurial intention mediated by motivation and attitude among management students. International Education Studies, 10(9), 61-69. Retrieved from https://www.researchgate.net/publication/319324852

Maresch, D., Harms, R., Kailer, N., \& Wimmer-Wurm, B. (2016). The impact of entrepreneurship education on the entrepreneurial intention of students in science and engineering versus business studies university programs. Technological Forecasting \& Social Change, 104, 172-179. doi: 10.1016/j.techfore.2015.11.006

McStay, D. (2008). An investigation of undergraduate student self-employment intention and the impact of entrepreneurship education and previous entrepreneurial experience (Doctoral Dissertation). Bond University, Australia. Retrieved from https://pure.bond.edu.au/ws/portalfiles/portal/18371119/

Mohammed, B. S., Fethi, A., \& Djaoued, O. B. (2017). The influence of attitude, subjective norms and perceived behavior control on entrepreneurial intentions: Case of Algerian students. American Journal of Economics, 7(6), 274-282. doi:10.5923/j.economics.20170706.02

Oosterbeek, H., Van Praag, C. M., \& IJsselstein , A. (2008). The Impact of Entrepreneurship Education on Entrepreneurship Competencies and Intentions: An Evaluation of the Junior Achievement Student MiniCompany Program. IZA Discussion Papers 364. Institute for the Study of Labor (IZA). Retrieved from https://ideas.repec.org/p/iza/izadps/dp3641.html

Rae, D. (2010). Universities and enterprise education: Responding to the challenges of the new era. Journal of Small Business and Enterprise Development, 17(4), 591-606. Retrieved from https://www.emeraldinsight.com/doi/abs/10.1108/14626001011088741

Rahman, H., \& Singh, H. R. (2013). Traits of successful entrepreneurs. International Journal of Scientific Research, 2(11), 292-294. doi:10.15373/22778179/NOV2013/9

Ramsey, J. B. (1969). Tests for Specification Errors in Classical Linear Least-Squares Regression Analysis. Journal of the Royal Statistical Society, 31(2), 350-371. Retrieved from https://www.jstor.org/stable/2984219

Samsom, K., \& Nandram, S. (2007). Entrepreneurial behavior: New perspectives gained through the critical incident technique. Nyenrode Research Papers Series, 07-04. doi: 10.2139/ssrn.982852

Sekaran, U., \& Bougie, R. (2010). Research methods for business: A skill-building approach (5th ed.). Haddington: John Wiley \& Sons

Shapero, A., \& Sokol, L. (1982). The social dimension of entrepreneurship. Encyclopedia of Entrepreneurship, 72-90. Retrieved from https://ssrn.com/abstract=1497759

Souitaris, V., Zerbinati, S., \& Al-Laham, A. (2007). Do entrepreneurship programmes raise entrepreneurial intention of science and engineering students? The effect of learning, inspiration and resources. Journal of Business Venturing, 22(4), 566-591. doi: 10.1016/j.jbusvent.2006.05.002

Tsordia, C., \& Papadimitriou, D. (2015). The role of theory of planned behavior on entrepreneurial intention of Greek business students. International Journal of Synergy and Research, 4(1), 23-37. Retrieved from http://ijsr.journals.umcs.pl

Velasquez, J. A., Arias, A. V., Hernandez, J. B., Diez-Echavarria, L. F., Marin, M. L., \& Perez, F. O. (2018). Characterization of entrepreneurial intention in university students as from systemic entrepreneurship intention model: A case study. Cuadernos de Gestion, 18(2), 95-144. doi:10.5295/cdg.160670jt

Weber, R. (2011). Evaluating entrepreneurship education. Munich: Springer.

Yordanova, D., \& Tarrazon, M. A. (2010). Gender differences in entrepreneurial intentions: Evidence from Bulgaria. Journal of Developmental Entrepreneurship, 15(3), 245-261. Retrieved from

https://www.worldscientific.com/doi/abs/10.1142/S1084946710001543 